\title{
Determinants of internal and external R\&D offshoring: Evidence from Spanish firms
}

\author{
Mery Patricia Tamayo ${ }^{*}$ \\ Universidad EAFIT and GRIPICO-Universidad Complutense de Madrid \\ Elena Huergo** \\ GRIPICO-Universidad Complutense de Madrid
}

\begin{abstract}
This paper analyzes the determinants of R\&D offshoring of Spanish firms using information from the Panel of Technological Innovation. We find that being an exporter, international technological cooperation, continuous R\&D engagement, applying for patents, being a foreign subsidiary, and firm size are factors that positively affect the decision to offshore R\&D. In addition, we find that a lack of financing is an obstacle relatively more important for independent firms than for firms that belong to business groups. For these latter, we also obtain that the factors that influence the decision to offshore R\&D differ depending on whether the firm purchases the R\&D services within the group or through the market: a higher degree of importance assigned to internal sources of information for innovation as compared to market sources increases (decreases) the probability of R\&D offshoring only through the group (market).
\end{abstract}

JEL Classification: L24, O32.

Key words: R\&D offshoring, firms' strategies, obstacles to innovation, independent firms, subsidiaries.

\footnotetext{
* Departamento de Economía, Universidad EAFIT, carrera 49 No 7 sur - 50, Medellín, Colombia. E-mail: $\underline{\text { mpta- }}$ mayo@eafit.edu.co.
}

** Dpto. Fundamentos del Análisis Económico I. Facultad de CC. Económicas y Empresariales. Universidad Complutense de Madrid. Campus de Somosaguas. 28223 Madrid. Spain. Tel.: +34 913942370. Fax: +34 913942561. E-mail: ehuergo@ccee.ucm.es.

This research has been partially funded by the Spanish Ministry of Economy and Competitiveness (project ECO2014-52051-R) and by the Community of Madrid across project S2015HUM-3417 (INNCOMCON-CM) COfunded by the European Social Fund. The authors are particularly grateful to two anonymous referees for useful comments. We also thank the seminar audiences at the European Network of the Economics of the Firm (ENEF) workshop (Madrid) and the R\&D Management Conference 2015 (Pisa). All errors are ours. 


\section{Introduction}

As Jensen (2009) points out, over the last decade, the offshoring of manufactures has taken a back seat to that of services, since demand has grown substantially for more advanced services in technical and administrative areas. Aspects such as the liberalization of trade, economic and regulatory reforms, and technological advances in communication, digitalization, and the new commercialization of certain goods are behind this change.

An important proportion of these exchanges of knowledge-intensive services corresponds to R\&D offshoring. For instance, the National Science Foundation (NSF) (2010) reports that, in the United States, there has been a rise of R\&D imports of around 23\% p.a. during the last decade. In parallel, the empirical literature about the determinants of R\&D offshoring at the firm level has also grown. ${ }^{1}$

In this analysis, it is relevant to distinguish between R\&D offshoring undertaken by independent firms and R\&D offshoring of multinationals, as the decisional context for multinational groups may fairly differ from the analysis on independent-domestic firms. In the case of firms in business groups, this technology decision may depend on the overall R\&D portfolio of the corporation, and the concept of R\&D offshoring can include international outsourcing of R\&D services, as well as R\&D purchases consisting of technology transactions within the group (internal or captive offshoring).

Mainly due to data restrictions, previous papers about the drivers or effects of R\&D offshoring use to refer specifically to one type of firms. For instance, in their study about the returns to foreign R\&D in the Netherlands, Belderbos et al. (2015) focus on Dutch firms that are not

\footnotetext{
${ }^{1}$ Some recent examples are the analyses made by Jabbour and Zuniga (2009, 2016), García-Vega and Huergo (2011), Martínez-Noya et al. (2012) and Holl and Rama (2014).
} 
foreign owned, as they do not have suitable data on the sourcing opportunities of affiliates through their parents.

Alternatively, other researchers consider a unique sample of innovative active firms and indicate whether or not the firm belongs to a (foreign) business group through a dummy variable. In this line, in their analysis for French manufacturing firms, Jabbour and Zuniga (2009) show that, within the sample of domestic companies, individual firms appear to be more active in international R\&D outsourcing than firms that belong to business groups. Using a similar methodology, Holl and Rama (2014) compare the technology sourcing via domestic R\&D outsourcing, international R\&D outsourcing, domestic cooperation for innovation and international cooperation for innovation of foreign subsidiaries and domestic firms. Their results for a sample of Spanish firms suggest not only that these choices are interdependent, but also that the behavior of foreign subsidiaries is different. In comparison with national subsidiaries, foreign subsidiaries show less propensity towards national R\&D outsourcing, as well as towards international R\&D outsourcing. However, through these analyses we cannot see whether R\&D offshoring is driven by different determinants in the case of independent firms in comparison with firms that belong to business groups.

The paper aims to contribute to this literature by comparing the drivers of R\&D offshoring between these two groups of firms. In addition, in the case of firms belonging to business groups, we focus on the determinants that guide the choice of the governance mode for R\&D offshoring. Specifically, we consider intra-group R\&D transactions as a sourcing alternative for firms in groups. To do this, we take advantage of the information on Spanish firms that offshore R\&D services, which is available in the Technological Innovation Panel (Panel de Innovación Tecnológica, henceforth referred to using its Spanish acronym PITEC). 
Our results confirm previous empirical literature about the determinants of R\&D offshoring: Regardless of whether the company belongs to a business group, being an exporting firm, international technological cooperation, continuous R\&D engagement, applying for patents, being a foreign subsidiary, and firm size increase both the probability of importing R\&D services and the offshoring intensity. However, the magnitude of the effects is generally greater in the case of firms in groups. On the other hand, we find that a lack of financing is an obstacle relatively more important for independent firms than for firms that belong to business groups. For these latter, we also obtain that the factors that influence the decision to offshore R\&D differ depending on whether the firm purchases the R\&D services within the group or through the market: a higher degree of importance assigned to internal sources of information for innovation as compared to market sources decreases the probability of R\&D offshoring through the market.

Understanding the factors that influence R\&D offshoring decisions is relevant regarding public policy, as there is evidence of a relation between the drivers of R\&D investment at foreign locations and domestic firm performance. At this respect, for Swiss firms, Arvanitis and Hollenstein (2011) obtain that knowledge-oriented motives of foreign R\&D have a positive impact on the innovation performance of domestic firms, while market- and resource-oriented strategies positively affect labor productivity.

As for the governance mode -captive vs external- of R\&D offshoring, in their analysis of Spanish firms, García-Vega and Huergo (2013) find that subsidiaries of foreign multinational firms which acquire R\&D services through the group are more innovative than the average innovative Spanish firm. Also for Spanish companies, Nieto and Rodríguez $(2011,2013)$ obtain that, although both modes of offshoring are positively related to innovation results and productiv- 
ity, the impact of captive offshoring on innovation outperforms the impact of offshore outsourcing. In addition, they find that offshoring also has a positive and indirect impact on productivity through innovation, and that this indirect effect is greater in captive offshoring than in international outsourcing.

\section{R\&D offshoring strategies: firms' motives and determinants}

The reasons why companies decide to carry out outsourcing or offshoring activities have been frequently analyzed in economic literature. They are basically associated with a reduction of costs and risks, with an increase in organizational flexibility, which allows a quicker adaptation to changing market needs, or with the generation of competitive advantages, freeing internal resources that can be engaged in core business activities.

However, these activities also entail disadvantages. In this regard, transaction cost theory, agency theory and the resource-based view are the approaches most used in the literature to explain why companies decide to outsource part of their production.

According to Coase (1937) and Williamson (1975, 1979, and 1981), the decision to internalize certain transactions or make them through the market depends on their costs, which may be associated with search costs, selection costs, bargaining costs and coordinating work. The higher these transaction costs are, the greater the propensity of firms to perform activities internally is, while they will outsource more insofar as transaction costs decrease.

From the agency theory perspective, the principal will try to establish the contract that best guarantees the optimal effort of the agent. This obviously implies agency costs associated 
with monitoring and evaluation, as opportunism is an important risk factor in an outsourcing contract (Aubert et al., 1998).

Consistent with the resource-based view, a need for access to complementary resources or capabilities that are not available within the company will be behind the outsourcing decision (Peteraf, 1993; Argyres, 1996). In the particular case of R\&D outsourcing, firms would benefit from the investments, innovations and specialized professional skills of external suppliers (McCarthy and Anagnostou, 2004).

To these arguments, we have to add other factors that influence the international dimension of offshoring. Regardless of the governance mode (through the group or through the market), one of the reasons to offshore may be the reduction of costs, especially labour costs, if tasks are outsourced in countries where wages are lower. Other reasons may be the intent to follow a growth strategy, competitive pressure or access to qualified personnel (Lewin and Peeters, 2006).

As for the specific case of R\&D offshoring, according to Martínez-Noya et al. (2012), the determinants of international $R \& D$ outsourcing would be related to both the international experience of the company and its skills and technological resources. The firm's experience in international markets would reduce the costs of search and selection of suitable foreign suppliers. In addition, we could expect that, by selling to a larger market, exporters decrease their financial constraints, making international outsourcing relatively less costly for them (García-Vega and Huergo, 2011). The studies by Jabbour and Zuniga (2009, 2016), GarcíaVega and Huergo (2011), and Holl and Rama (2014) gather clear evidence of the positive relation between the exporting character of firms and international R\&D outsourcing. 
Furthermore, although greater internal capabilities can make international outsourcing less necessary, because of the complexity of the innovation process, firms could find it more efficient to outsource non-core parts of this process in foreign countries where they have leading or cheaper suppliers. ${ }^{2}$ This strategy would help companies to reduce their operating costs, achieving a greater focus on their core competencies (McCarthy and Anagnostou, 2004). In addition, internal resources and capabilities can increase firms' absorptive capacities of foreign knowledge, stimulating the complementarity between internal and external R\&D (Cassiman and Veugelers 2006; Goyal et al. 2008).

One of these internal resources is qualified employment. Representatives of the theory of human capital (Hamermesh, 1980, 1993; Kremer, 1993; Dunne and Schmitz, 1995) highlight the complementarity between physical and human capital, the advantages derived from grouping qualified workers with other qualified workers, and the improved capacity to amortize fixed costs associated with hiring qualified workers. For this reason, it seems logical to think that firms' employment in internal R\&D activities would be complementary to R\&D offshoring.

In the same line, it is also expected that obstacles to innovation have a negative effect on the decision to invest in technological activities and, therefore, on the decision to offshore R\&D (Garcia and Huergo, 2011). According to Chaney (2013), when faced with fixed costs associated with exporting and liquidity restrictions, for some firms it would be profitable to export, but they decide not to because of the doubts that they have that liquidity is not enough. Something similar may occur with the offshoring of R\&D services if the search for foreign

\footnotetext{
${ }^{2}$ In this sense, the reasons for R\&D offshoring may vary considerably depending on the relative levels of (technological and economic) development of the investing and host countries (Hall, 2011).
} 
suppliers generates sunk costs that increase in a context of financial constraints or lack of information.

To summarize, according to previous literature, the more international experience and technological resources and capabilities the firm possesses and the less transaction costs of international transfers, the more likely it will outsource R\&D services internationally compared to other sourcing strategies.

However, we might think that the intensity of these relationships may differ between individual firms and companies that belong to business groups. In the latter case, the offshoring decision may depend on the overall R\&D portfolio of the corporation. Companies in business groups not only have the option of performing international R\&D outsourcing, but also internal captive offshoring, i.e., outsourcing part of the production process in companies from the same group located abroad. Moreover, as Guzzini and lacobucci (2014) point out for Italian manufacturing firms, the organization and diversification of business groups can influence the R\&D investment of subsidiaries. In particular, these authors find that less diversified groups are more likely to centralize R\&D, while in more diversified groups firms are more likely to be autonomous.

Taking this in mind, in this paper we focus on two firm characteristics that can differently affect the offshoring decision of companies in business groups with respect to independent firms: The access to external finance and the management of information.

As for the first aspect, firms in groups and especially multinationals can benefit from the resources and capabilities of the corporation. Companies belonging to groups are supposed to have easier access to finance, technological knowledge or trained people, because of the 
close relations with other group members (Guzzini and lacobucci, 2014). As a consequence, they tend to perceive financial obstacles to innovation as significantly less relevant than independent firms (lammarino et al., 2009).

However, we must take into account that, besides the belonging to a group, other firm characteristics can be related to the existence of financial constraints. In particular, previous empirical evidence suggests that export participation can improve firm financial health (Greenaway et al., 2007). Although firms have to incur large sunk costs to enter into export markets (Campa, 2004), exporters could benefit from more stable cash flows because of the international diversification of their sales (Bridges and Guariglia, 2008). Therefore, we propose the following hypothesis:

Hypothesis 1: Conditional on firms having the same exporting status, when companies decide to offshore $R \& D$ services, a lack of financing is an obstacle relatively more important for independent firms than for firms belonging to business groups.

Regarding the second aspect, affiliated firms can internalize within the group the knowledge spillovers resulting from the innovative effort. In the case of R\&D offshoring, this fact may influence the selection of the governance model (internal or external) in contexts of technology leakage. External R\&D offshoring implies higher risks in situations of imperfect contracts, hold-up problems, and cultural differences (e.g., Baccara, 2007, Lai et al., 2009, Ornelas and Turner, 2008), making firms more sensitive to a lack of information. Companies in groups can be prone to offshoring through the group, avoiding exposure to subcontractors, especially in countries with poor intellectual property rights (García-Vega and Huergo, 2011). For the same reason, we can expect that the selection of the offshoring channel depends on the relevance that companies allocate to internal sources of information in order to innovate 
as compared to external sources of information and, specifically, to market sources of information. On the basis of these arguments, the following hypotheses are put forward:

Hypothesis 2: In the case of firms belonging to business groups, a lack of information is an obstacle relatively more important for external R\&D offshoring than for internal R\&D offshoring.

Hypothesis 3: Firms belonging to business groups that find internal sources of information for innovation very relevant compared to market sources of information are less likely to offshore $R \& D$ services through the market.

\section{Database}

Our empirical analysis is done with the information provided in the Panel of Innovation Technology (PITEC), from 2004 to 2010. The PITEC is a statistical database created in the format of panel data and the result of the joint effort by the Spanish Foundation for Science and Technology (FECYT), the National Institute of Statistics (INE), and the Cotec Foundation along with assessment by a group of academic experts. Its goal is to facilitate the monitoring of technological innovation activities by Spanish firms ${ }^{3}$.

The panel is selected on the basis of two national surveys carried out by the INE in the innovation sector: "Survey on Technological Innovation of Firms" (the Spanish version of the Community Innovation Survey) and "Statistics on R\&D Activities". The panel covers all the business sectors gathered in the National Classification of Economic Activities (NACE). This is

\footnotetext{
${ }^{3}$ The PITEC is publicly available to researchers at: http://icono.fecyt.es/PITEC/Paginas/por que.aspx. The files accessible on this site correspond to the files maintained by INE, except for the "anonymization" of a series of variables so that corresponding firms cannot be identified. López (2011) shows that the expected biases due to this anonymization are small through the comparison of regressions that use original and harmonized data alternatively.
} 
a unique dataset that includes representative samples of the universe of firms that are trying to innovate and of the rest of the companies that operate in Spain. Although the PITEC includes a sample of firms that do not undertake technological activities, given the objective of this study, we focus the analysis on the sample of innovative active firms, that is, firms that have positive expenditures associated with innovation activities during the period. These activities can consist of R\&D done within the firm (internal R\&D), R\&D performed outside the firm through a contract or an agreement (external R\&D), the acquisition of machinery, equipment and software, or the acquisition of other external knowledge. Therefore, our analyses and results are conditional to firms being active in innovation markets (with any type of innovation expenditures).

There are, on average, around 7,500 companies with innovation expenditures in the PITEC each year. Overall, our final sample consists of an unbalanced panel of 31,425 observations, 12,659 of which correspond to companies that belong to a business group.

In the PITEC, companies answer questions related to internal and external R\&D. They also specify whether the purchase of R\&D services takes place in Spain or abroad, and whether the suppliers are firms from the same group, firms outside the group, public institutions, universities, etc. With this in mind, we will use the term R\&D offshoring for purchases of R\&D services abroad, regardless of the provider's location.

Most firms in our sample do not offshore R\&D; only around 7\% are R\&D offshorers. This percentage is constant throughout the time period. As we mentioned in the introduction, it is important to differentiate between the following two cases: when suppliers are firms from the same business group, and when purchases are made from the market; in other words, when suppliers are firms outside the group, public research centers, universities, etc. 
In Table 1, we see the number of observations that correspond to firms from the PITEC that offshore R\&D and whether or not these firms belong to a group, specifying whether the suppliers of R\&D services are firms from the group or other firms and institutions. It is obvious that independent firms can only acquire R\&D services outside the group. On the other hand, note that even in multinational firms, the majority of offshoring consists of suppliers outside the group and in only a small percentage of cases (9.2\%) do firms combine suppliers of both types.

Insert Table 1 about here

As for the intensity of R\&D offshoring (defined as the percentage of R\&D purchases from foreign providers over the total amount of R\&D purchases), in Figure 1 we can see that, regardless of whether the firm has a group, offshorers tend to combine foreign purchases with purchases in Spain. Nevertheless, the percentage of imports is higher in firms that belong to a group.

Insert Figure 1 about here

Moreover, it is worth mentioning that the intensity of external R\&D outsourcing is also higher in firms in groups, which would at first seem to contradict the findings put forward by Jabbour and Zuniga (2009) for a sample of French firms from 1993 to 2001, according to which individual firms were the most active in international R\&D outsourcing. However, with a similar sample for the same period, Jabbour and Zuniga (2016) find no significant difference between independent firms and affiliates of domestic or multinational French groups in terms of R\&D offshoring once they take into account the availability of R\&D resources at the domestic level. This is one of the issues which will be more deeply analyzed in this paper. 


\section{Empirical model and variables}

To analyze the determinants of R\&D offshoring, we estimate two different types of specifications. First, we turn our attention to the factors that affect this activity for the whole sample of innovative firms. The analysis refers to the extensive margin (the decision to offshore) as well as to the intensive margin (the magnitude of the purchases of R\&D services). ${ }^{4}$ This study is done through the estimation of a generalized Tobit model, where two equations are estimated simultaneously for maximum likelihood. The first equation refers to the firm's decision to buy R\&D services abroad (selection equation), while the second refers to the intensity with which purchases are made (intensity equation).

More formally, the model is the following: the intensity of R\&D offshoring of firm $i$ in the year $t$ is described by using the latent variable oss ${ }_{i t}^{*}$ :

$$
\text { oss }_{i t}^{*}=z_{i t}^{\prime} \beta+e_{i t},
$$

where $z_{i t}$ is a vector of determinants for R\&D offshoring intensity that is measured as the percentage that purchases of $R \& D$ services abroad represent in the total amount of $R \& D$ service purchases.

However, this intensity is only observed if the firm decides to import R\&D services. The selection equation is expressed by the following equation:

$$
\operatorname{doss}_{i t}\left\{\begin{array}{ll}
=1 & \text { if } \pi \operatorname{coss}_{i t}^{*}=F\left(X_{i t}^{\prime} b+u_{i t}\right)>0 \\
=0 & \text { otherwise }
\end{array},\right.
$$

\footnotetext{
${ }^{4}$ As Markusen (2005) suggests, although liberalization allows the trade volume of already-existing products to expand (intensive margin), the increase in service offshoring is also related to the expansion of trade in the extensive margin, since new tasks can be commercialized because of innovation in communication and technology.
} 
where doss $_{i t}$ represents the decision of firm $i$ in the year $t$ to buy R\&D services abroad as a binary variable that takes the value of 1 when the firm does R\&D offshoring and 0 otherwise, $\pi$ oss $^{*}$ is a latent variable that can be interpreted as expected benefits of that decision, $X$ is the vector of explanatory variables and $u$ is the error term.

Conditioned on whether the firm imports R\&D services, we can observe the intensity of this activity:

$$
\text { oss }_{i t}=\left\{\begin{array}{cccc}
\operatorname{oss}_{i t}^{*}=z_{i t}^{\prime} \beta+e_{i t} & \text { if } & \text { doss }_{i t}=1 \\
0 & \text { if } & \text { doss }_{i t}=0^{\prime}
\end{array}\right.
$$

where we assume that the error terms $u$ and $e$ follow a bivariate normal distribution with mean zero, $\sigma_{U}=1$ and $\sigma_{e}$, and coefficient of correlation $\rho$. Note that in this case we do not distinguish between internal and external R\&D offshoring. Given the panel structure of our database, we estimate this model as a Random Effects Tobit model.

Secondly, we focus on the subsample of firms that belong to business groups and that therefore can purchase R\&D services through two different (non-exclusive) channels: from other companies in the group or from the market (firms or institutions outside the group). As observed when analyzing the distribution of R\&D offshorers, only a small percentage of firms that belong to a business group undertake both internal and external R\&D offshoring, while the majority choose a single channel when they make purchases of foreign R\&D.

As a way to further explore the behavior of firms that belong to a group, a bivariate Probit or Biprobit model is estimated. This allows us to gain a better understanding of the elements that lead firms to choose different channels at the moment of offshoring R\&D. Just as Greene (2003) suggests, the bivariate Probit model is an extension of the multi-equational 
models of classical regression, in which a system of equations where errors are correlated is considered. According to Zellner and Huang (1962), taking into account the correlation between the perturbations, one may obtain more efficient estimations than if each equation is estimated separately.

For the specific case of internal and external R\&D offshoring, the specification of the biprobit model is the following:

$$
\begin{aligned}
\text { doss }_{i t}^{\prime} & = \begin{cases}1 & \text { if } \pi o s s_{i t}^{\prime^{*}}=w_{i t}^{\prime} b_{1}+\mu_{1 i t}>0 \\
0 & \text { otherwise }\end{cases} \\
\text { doss }_{i t}^{E} & = \begin{cases}1 & \text { if } \pi o s s_{i t}^{E^{*}}=w_{i t}^{\prime} b_{2}+\mu_{2 i t}>0 \\
0 & \text { otherwise }\end{cases}
\end{aligned}
$$

where doss $_{i t}^{\prime}$ and doss $_{i t}^{E}$ represent the decisions by firm $i$ in year $t$ to undertake internal or external R\&D offshoring, respectively, with both variables as a binary that takes the value 1 when the firm does R\&D offshoring and 0 otherwise. The vector $w$ corresponds to the explanatory variables related to the specific characteristics of the firm. The error terms of these equations follow a normal distribution with $E\left[\mu_{1 i t}\right]=E\left[\mu_{2 i t}\right]=0$, $\operatorname{Var}\left[\mu_{1 i t}\right]=\operatorname{Var}\left[\mu_{2 i t}\right]=1$ and $\operatorname{Cov}\left[\mu_{1 i t}, \mu_{2 i t}\right]=\rho_{I E}$.

In both models, we include the same set of independent variables. ${ }^{5}$ The key explanatory variables to test our hypotheses refer to the obstacles to innovate and the sources of information for innovation. As for the first, The PITEC allows us to consider the lack of financing and the lack of information as factors that hinder innovation. The lack of financing is associated with the lack of a firm's own funds, the lack of external financing, and innovation costs. In the survey, firms value each of these factors on a scale of 0-3 (irrelevant, low importance,

\footnotetext{
${ }^{5}$ The main statistics that describe these variables can be found in Table 2.
} 
medium importance, or high importance), the average of the factors serving as an indicator of lack of financing. As for lack of information, two aspects are taken into consideration: a lack of information about technology and a lack of information about markets. The way to quantify them is the same as in the previous case. The difference of means tests show that both obstacles to innovation have more importance for independent firms than for firms belonging to groups (Table 2).

Insert Table 2 about here

To gain information for new or ongoing innovative projects, firms can benefit from different sources. In the survey, firms declare the importance of internal, institutional, and market sources in order to innovate. In particular, firms indicate whether the sources of information have high, medium, or low importance, or no importance at all. Based on the answers, we assign for each of the three types of sources a dummy variable which takes the value 1 if the evaluation given by the firm for that source type is high, and zero otherwise. Internal sources refer to whether the information comes from the same firm or from the business group. As for external sources, institutional sources concern universities or other higher education centers, public research bodies or technology centers. Market sources market refer specifically to whether the information was obtained from suppliers of equipment, material, components or software, from clients, competitors or other firms from the same branch of activity, or by consultants, commercial laboratories or private R\&D institutions. Note that, among external sources, institutional sources could be more related to the use of basic research knowledge (universities, public research organization, etc.) than market sources. Basic research would probably be more demanding in terms of face-to face interaction and more 
risky to outsource. If this is so, we could expect a different impact of these two types of external sources in firms' tendency to offshore R\&D through the market.

Given that our hypothesis 3 refers to the relative importance that the firm assigns to internal sources in comparison to external sources, we have also constructed a dummy variable that takes the value 1 when the firm indicates that internal sources of information have high (medium) importance for innovation while market sources have low (null) importance.

The choice of the rest of explanatory variables follows previous literature on the determinants of R\&D strategies described in Section 2. Therefore, through these variables we want to reflect previous experience in foreign markets, firm technological resources and capabilities, and transaction costs of international transfers.

The indicator of international experience most used in this context is the exporting character of the firm. In this line, we use a dummy variable that indicates whether the firm is an exporter. This variable also acts as a control for testing our first hypothesis, given that the exporting status can be correlated to the perception of the lack of finance as an obstacle to innovate. A second indicator of the firm international experience is a dummy variable that takes the value one if the firm undertakes international technological cooperation. As can be seen in Table 2, the difference of means test shows that international experience is higher among firms that belong to business groups.

To measure a firm's technological resources and capabilities, we use a wide range of indicators. Firstly, we take into account the firm's $R \& D$ employment as percentage of total employment. The information in the PITEC allows us to distinguish what part of a firm's total employment corresponds to R\&D researchers. The term researcher refers specifically to pro- 
fessionals who work on the creation of new concepts, products or processes, methods and systems, and on the management of their respective projects.

Secondly, in the database, firms declare whether they have performed in-house continuous $R \& D$ activities and whether they have been a patent applicant in the last three years. With this information, we have created two dummy variables that take the value 1 if, respectively, the firm engages in R\&D continuously or if it has applied for patents in the current year or in the previous two years.

Finally, we also consider firm size (measured as the logarithm of the number of workers). Several authors have analyzed the relation between firm size and technological inputs. As for offshoring strategy, traditionally we might think that large firms find providers abroad more easily, especially with regard to manufacturing activities. However, given the technological developments of the last few decades, searching costs have decreased, benefiting both large and small companies.

Chen and Sen (2015) propose that the effect of scale economies can drive both integrated and disintegrated downstream firms to offshore intermediate goods. In a context of economies of scale in upstream production, a disintegrated downstream firm would tend to purchase intermediate goods from a pure offshore provider rather than its vertically integrated rival. And a vertically integrated firm would also outsource offshore because of the incentive to exploit scale economies.

From the empirical point of view, the evidence about the link between firm size and R\&D offshoring is not conclusive. For example, Chang and Robin (2006) confirm that firm size is a key variable for explaining R\&D intensity and technology imports in Taiwanese manufactur- 
ing firms, following the pattern of an inverted U. For Japanese firms, Hideo and Sadao (2011) find that a larger company tends to generate more patents from a research project but not more valuable patents, concluding that the main source of such a scale economy is not internal knowledge inflow but the "appropriation advantage" of a large firm.

Note that, in general, in our sample, the indicators of firms' technological resources and capabilities show a greater average for firms in business groups. The remarkable exception is $R \& D$ employment, which is statistically higher in independent domestic companies.

Regarding the transaction costs of technology transfers, some authors relate them to the complexity of technology (McCarthy and Anagnostou, 2004). However, the PITEC has no enough information to measure the specificity of technological assets in an accurate way. In this sense, it would be interesting to merge this database with the information about patents, as suggested by Thoma et al. (2010). However, due to the anonymization process, we cannot merge the PITEC with any other sources containing technology-level indicators. As a rough measure, we take into account whether the firm operates in a sector of medium-high technology according to the NACE-2009 classification.

As control variable, we also add an indicator of whether the firm is a foreign subsidiary. In particular, we identify foreign subsidiaries through a dummy variable which takes the value 1 if the firm is a private foreign subsidiary with at least $50 \%$ participation of foreign capital. ${ }^{6}$ Recent papers suggest a different sourcing behavior of foreign subsidiaries as compared to that of domestic affiliates (Holl and Rama, 2014; García-Sánchez et al., 2015). Foreign subsid-

\footnotetext{
${ }^{6}$ In PITEC, enterprises belonging to groups specify whether they are parent companies, subsidiaries, joint ventures or associate companies. Note that for firms in groups, data in our database are not consolidated. In this sense, the Spanish Innovation Survey follows the Community Innovation Survey that includes the following statement in the harmonized survey questionnaire: "If your enterprise is part of an enterprise group: Please answer all further questions about your enterprise only for the enterprise for which you are responsible in [your country]".
} 
iaries may have easier access to available international technology through the use of their group's network of establishments worldwide (Veugelers and Casssiman, 2004). In addition, if we assume that the benefits of internalization are generated as a result of avoiding the imperfections of foreign markets (Buckley and Casson, 1976), in presence of market imperfections foreign subsidiaries would be more prone to use the group as the channel for their technology transfers. However, if we think that foreign-owned firms mainly produce for the domestic market, we would expect them to be more likely to offshore R\&D services through the market (Arvanitis and Hollenstein, 2011).

\section{Results}

As we have explained before, to analyze the determinants of R\&D offshoring, we estimate two different types of specifications. Firstly, we estimate a Random Effects (RE) generalized Tobit model for the probability of offshoring and the intensity of this activity. Secondly, we use a Biprobit model to focus on the subsample of firms that belong to business groups and that therefore can purchase R\&D services through two different channels: from other companies in the group (internal offshoring) or from the market (external offshoring). In order to alleviate simultaneity problems, the main time-variant explanatory variables are included in the estimations lagged one period. ${ }^{7}$

The results for the RE generalized Tobit model are reported in Table 3. As for the decision to undertake R\&D offshoring (column (1)), being an exporter, international technological cooperation, continuous R\&D engagement, R\&D employment, applying for patents, and institutional and market sources of information have a positive impact. In particular, when a firm is

\footnotetext{
${ }^{7}$ In each Table of this paper, we denote by $(\mathrm{t}-1)$ the variables that are lagged.
} 
an exporter, the probability of undertaking R\&D offshoring rises by 2.1 percentage points. Companies in medium and high-tech services activities also exhibit a higher propensity to offshore R\&D. In addition, the effect of size shows a non-linear association with the probability of offshoring, while both obstacles to innovation and internal sources of information do not seem to affect the probability of importing R\&D services. These results are coherent with previous evidence, globally confirming that the more international experience and the more technological resources and capabilities the firm possesses, the more likely it will offshore R\&D services.

Insert Table 3 about here

As for intensity of R\&D offshoring, marginal effects in column (2) show that the international experience and most of the variables that represent firm technical capabilities keep a positive effect. Moreover, in line with the descriptives of Table 1 and Figure 1, being a foreign subsidiary increases both the probability of offshoring and its intensity. This result is consistent with the idea that foreign subsidiaries can benefit from an easier access to available international technology through the use of their group's network of establishments worldwide.

This Tobit model is also estimated by distinguishing between individual independent firms and those companies that belong to a business group (Table 4). Irrespective of belonging to a business group, exporter character, international technological cooperation, continuous R\&D engagement, R\&D employment and applying for patents keep their positive impact on the probability of undertaking R\&D offshoring. However, marginal effects of these variables are globally higher in the case of firms in groups. 
However, a lack of finance decreases the probability of importing R\&D services exclusively in independent firms, although the effect is weak. This last result gives support to our hypothesis 1 , pointing out that a lack of funding is an obstacle relatively more important for the offshoring decision in the case of independent firms in comparison to firms that belong to business groups.

Insert Table 4 about here

As for the intensity of R\&D offshoring, variables related to firm technological resources and capabilities keep a positive impact regardless of whether the company belongs to a business group. However, we can also see significant differences between the two sub-samples of firms. Independent firms that operate in high or medium-tech services sectors and that consider institutional sources of information very important for innovation show higher offshoring intensities. On the other hand, market sources of information are much more relevant for the firms in groups. In addition, note that the lack of finance keeps a negative impact on $R \& D$ offshoring for independent firms and has a non-significant effect in the case of firms in groups.

Nevertheless, as we have mentioned before, the participation in export markets can be positively associated with a lower perception of financial constraints, especially in the case of independent firms. Although the specification estimated in Table 4 includes the exporting status as a control variable, as robustness check in Table 5 we show the results that we ob- 
tain when we additionally distinguish between the sub-samples of exporters and nonexporters. ${ }^{8}$

\section{Insert Table 5 about here}

In general, the results are similar to those in table 4. As it is displayed in of Table 5, most variables associated with technological resources and capabilities keep their positive impact in the two sub-samples of firms irrespective of belonging to a business group, although the magnitude of marginal effects is higher for non-exporters than for exporters. The remarkable exception is R\&D employment, which seems to be irrelevant for independent non-exporters. The lack of finance shows a negative coefficient in all estimates, but surprisingly the marginal effect is statistically different from zero only in the case of independent exporting companies.

Also as a robustness check, we distinguish between firms in high-tech and low-tech activity sectors (Table A.1 of Appendix 1). As expected, prior international experience and own technological resources have in general a greater importance for firms operating in high-tech activity sectors. On the other hand, a lack of financing negatively affects R\&D offshoring only in firms that are independent and operate in low-tech sectors.

Until now, we have analyzed the determinants of firms' decisions on R\&D offshoring without distinguishing between internal and external R\&D offshoring. However, in the case of firms that belong to business groups, the decisions to offshore R\&D services through the group or through the market could be correlated. Therefore, we also undertake an estimation of the

\footnotetext{
${ }^{8}$ For simplicity, in this Table we only show marginal effects for the expected value of R\&D offshoring intensity conditional on offshoring R\&D. Marginal effects for the probability of offshoring are available from the authors upon request.
} 
determinants of these two decisions through a bivariate Probit model (Table 6). The coefficient $\rho_{I E}$ is significant, indicating that for firms that belong to business group, the decisions to do R\&D offshoring within the group or through the market are correlated.

Note that this model is estimated only for companies in groups, which are the ones for which the choice of governance mode is relevant. It is also noteworthy that, as in the univariate Probit model, the estimated coefficients in the bivariate Probit model do not directly quantify the increase in the probability given a marginal change in an independent variable. Instead, it is necessary to calculate the partial derivatives or marginal effects, which are presented in columns (1) and (2) of Table 6. In addition, from estimated coefficients of the bivariate Probit model, we can also compute the marginal effects associated with the following joint probabilities: offshoring $R \& D$ only internally $\left(\operatorname{Pr}\left(\right.\right.$ doss $^{\prime}=1$, doss $\left.\left.^{E}=0\right)\right)$, offshoring $R \& D$ only externally $\left(\operatorname{Pr}\left(\right.\right.$ doss $^{\prime}=0$, doss $\left.\left.^{E}=1\right)\right)$, offshoring $R \& D$ through both channels $\left(\operatorname{Pr}\left(\right.\right.$ doss $^{\prime}=1$, doss $\left.\left.^{E}=1\right)\right)$, and not undertaking R\&D offshoring $\left(\operatorname{Pr}\left(\right.\right.$ doss $^{\prime}=0$, doss $\left.\left.^{E}=0\right)\right)$. These effects are reported in columns (3) to (6) of Table 6.

Insert Table 6 about here

We can observe that the results for most variables show tendencies and magnitudes similar to the ones in Table 4 for firms in groups. Regardless of the governance mode, being an exporting firm, international technological cooperation, R\&D employment and belonging to a high or medium-tech manufacturing sector positively affect R\&D offshoring. Firm size also keeps its non-linear impact. 
However, there are some remarkable differences regarding information variables. A lack of information is a less relevant obstacle for internal R\&D offshoring than it is for external R\&D offshoring. Similarly, we find that a high relevance of internal sources of information decreases the probability of offshoring R\&D services through the market. The opposite happens regarding external sources of information: firms that assign a high importance to institutional and market sources are more prone to offshore externally. In addition, a relative higher importance of the internal sources as compared to market sources negatively affects the probability of importing R\&D services only externally (column (4) of Table 6), while it increases the probability of R\&D offshoring only through the group (column (3) of Table 6). These latter results provide evidence for our hypotheses 2 and 3.

It is also noteworthy that these regularities are captured once we control for the firm's status as foreign subsidiary. Being a foreign subsidiary has a negative effect on the propensity to offshore R\&D externally, while the effect is the opposite regarding internal R\&D offshoring. In addition, in terms of joint probabilities, this status increases the probability of offshoring R\&D only internally or through both channels (columns (3) and (5) of Table 6) and decreases the propensity to import R\&D services only through the market (column (4)). This result is coherent with the idea that, in presence of market imperfections, foreign subsidiaries would be more prone to use the group as the channel for their technology transfers.

\section{Conclusions}

Although the literature on determinants of service offshoring has grown substantially in the last few years, there is still relatively very little information on this subject that looks at individual firm data and compares the behavior of independent firms with the strategies of firms 
belonging to business groups. This paper aims to gain a deeper understanding of this process, taking advantage of the information on Spanish firms that offshore R\&D services, which is available in the Technological Innovation Panel (PITEC) constructed by the Spanish Statistical Institute.

The analysis is limited to firms with innovation expenditure, which is an average of 7,500 a year. According to this data, approximately $7 \%$ of innovative firms offshore $R \& D$, with $R \& D$ offshoring intensity (percentage of purchases of foreign R\&D services over total R\&D purchases) around 5\% and $14.3 \%$, respectively, in individual firms and in firms that belong to business groups.

Our results provide evidence that, irrespective of belonging to a business group, exporting character, international technological cooperation, continuous R\&D engagement, R\&D employment and applying for patents show a positive impact on both the probability of importing R\&D services and the offshoring intensity. However, marginal effects are generally lower in the case of independent firms. On the other hand, a lack of financing is an obstacle relatively more important for independent firms than for firms that belong to business groups. These latter firms, especially if they are subsidiaries of multinationals, could benefit from the resources and capabilities of the group and therefore would perceive obstacles to innovation as significantly less relevant than independent firms.

In order to clarify the factors that influence the decision to offshore R\&D for firms that belong to a business group, we also distinguish between offshoring R\&D services through the market (international R\&D outsourcing) or purchasing R\&D services abroad within the group. This also allows for analyzing the determinants of each of the following options: not undertaking R\&D offshoring, offshoring R\&D only within the group, offshoring R\&D only through 
the market, and offshoring R\&D through both channels. The results confirm the positive effect that international experience of firms and R\&D employment have on all types of R\&D offshoring. Furthermore, we find that some variables have a different effect depending on the strategy followed by the firm: a lack of information is an obstacle relatively more important for external R\&D offshoring than for internal R\&D offshoring. In particular, if the firms find internal sources of information for innovation very relevant as compared to market sources of information, they will be less prone to offshore R\&D services only through the market. These regularities are captured after controlling for the firm's status as foreign subsidiary, which has a positive (negative) effect on the propensity to offshore R\&D internally (externally).

Our paper has some limitations. First, firms in our database do not identify the host regions or countries of foreign R\&D. Therefore, we cannot consider certain motives for R\&D offshoring related to location advantages. Second, our data restrictions also affect the information about the complexity of knowledge and the overall R\&D portfolio of groups, which would help to discriminate the choice between captive and external offshoring. Third, although we have taken advantage of the panel structure of the data to alleviate endogeneity problems, further studies are needed for a better understanding of the dynamics in the relationships among sourcing strategies. These limitations could be the starting point for future lines of research. 


\section{References}

Argyres, N. (1996) Evidence on the role of firm capabilities in vertical integration decisions, Strategic Management Journal, 17, pp. $129-150$.

Arvanitis, S. and Hollenstein, H. (2011) How do different drivers of R\&D investment in foreign locations affect domestic firm performance? An analysis based on Swiss panel micro data, Industrial and Corporate Change, 20(2), pp. 605-640.

Aubert, B. A., Patry, M. and Rivard, S. (1998) Assessing the risk of IT outsourcing, System Sciences, Proceedings of the Thirty-First Hawaii International Conference on, 6, pp. 685692.

Baccara, M. (2007) Outsourcing, Information Leakage and Consulting Firms, RAND Journal of Economics, 38(1), pp. 269-289.

Belderbos, R., Lokshin, B. and Sadowski, B. (2015) The returns to foreign R\&D, Journal of International Business Studies, 46, pp. 491-504.

Bridges, S. and Guariglia, A. (2008) Financial constraints, global engagement, and firm survival in the United Kingdom: Evidence from micro data, Scottish Journal of Political Economy, 55(4), pp. 444-64.

Buckley, P. J. and Casson, M. (1976) The Future of Multinational Enterprise. Macmillan: London.

Campa, J. (2004) Exchange rates and trade: How important is hysteresis in trade? European Economic Review 48(3), pp. 527-48.

Cassiman, B. and Veugelers, R. (2006) In search of complementarity in innovation strategy: internal R\&D and external technology acquisition, Management Science, 52(1), pp. 68-82.

Coase, R. (1937) The nature of the firm, Economica New Series, 4, pp. 386-405. 
Chaney, T. (2013) Liquidity Constrained Exporters, NBER Working paper No. 19170, National Bureau of Economic Research.

Chang, C.-L. and Robin, S. R. (2006) Doing R\&D and/or Importing Technologies: The Critical Importance of Firm Size in Taiwan's Manufacturing Industries, Review of Industrial Organization, 29(3), pp. 253-278.

Chen, Y. and Sen, D. (2015) Strategic outsourcing under economics of scale, Bulletin of Economic Research, 67(2), pp. 1467-8586.

Diaz-Mora, C. (2008) What factors determine the outsourcing intensity? A dynamic panel data approach for manufacturing industries, Applied Economics, 40(19), pp. 25092521.

Dunne, T. and Schmitz, J. (1995) Wages, employer size-wage premia and employment structure: Their relationship to advanced-technology usage at U.S. manufacturing establishments, Economica, 62, pp. 89-107.

García-Sánchez, A., Molero, J. and Rama, R. (2015) Are 'the best' foreign subsidiaries cooperating for innovation with local partners? The case of an intermediate country, Science and Public Policy. DOI: 10.1093/scipol/scv057.

García-Vega, M. and Huergo, E. (2011) Determinants of International R\&D Outsourcing: The role of trade, Review of Development Economics 15(1), 93-107.

García-Vega, M. and Huergo, E. (2013) Multinationals' Technology Transfers and firms' performance, in: S. Beugelsdijk, S. Brakman, H. van Ees and H. Garretsen (eds.), Firms in the International Economy: Firm Heterogeneity Meets International Business, CESifo Seminar Series, The MIT Press.

Goyal, S., Moraga-González, J. and Konovalov, A. (2008) Hybrid R\&D, Journal of the European Economic Association, 6(6), pp. 1309-1338. 
Greenaway, D., Guariglia, A. and Kneller, R. (2007) Financial factors and exporting decisions, Journal of International Economics, 73(2), pp. 377-395.

Greene, W. (2003) Econometric Analysis. Prentice Hall. New Jersey: Fifth Edition.

Guzzini, E. and Iacobucci, D. (2014) Business Group Affiliation and R\&D, Industry and Innovation, 21(1), pp. 20-42.

Hall, B. H. (2011) The internationalization of R\&D, MERIT Working Papers 049, United Nations University - Maastricht Economic and Social Research Institute on Innovation and Technology (MERIT).

Hamermesh, D. S. (1980) Commentary, in: J. J. Siegfried (ed.), The Economics of Firm Size, Market Structure and Social Performance, Washington D.C.: Federal Trade Commission.

Hamermesh, D. S. (1993) Labor Demand. Princeton, NJ: Princeton University Press.

Holl, A. and Rama, R. (2014) Foreign subsidiaries and technology sourcing in Spain, Industry and Innovation, 21(1), pp. 43-64.

lammarino, S., Sanna-Randaccio, F. and Savona, M. (2009) The perception of obstacles to innovation. Foreign multinationals and domestic firms in Italy, Revue d'économie industrielle, 1, pp. 75-104.

Jabbour, L. and Zuniga, M. P. (2009) Drivers of the offshore outsourcing of R\&D: Empirical evidence from French manufacturers, Discussion Papers 09/04, University of Nottingham, GEP.

Jabbour, L. and Zuniga, M. P. (2016) The outsourcing of research and development in global markets: evidence from France, World Economy, 39(3), DOI: 10.1111/twec.12373.

Jensen, P. (2009) A learning perspective on the offshoring of advance service, Journal of international Management, 15, pp. 181-193. 
Kremer, M. (1993) The O-Ring Theory of Economic Development, The Quarterly Journal of Economics, 108, pp. 551-75.

Lai, E., Riezman, R. and Wang, P. (2009) Outsourcing of innovation, Economic Theory, 38(3), pp. $485-515$.

Lewin, A. and Peeters, C. (2006) The top-line allure of off-shoring, Harvard Business Review, March, pp. 22-24.

López, A. (2011) Effect of microaggregation on regression results: an application to Spanish innovation data, The Empirical Economics Letters, 10(12), pp. 1265-1272.

Martínez-Noya, A., Garcia-Canal, E. and Guillen, M.F. (2012) International R\&D service outsourcing by technology-intensive firms: Whether and where? Journal of International Management, 18(1), pp. 18-37.

McCarthy, I. and Anagnostou, A. (2004) The impact of outsourcing on the transaction costs and boundaries of manufacturing, International Journal of Production Economics, 88, pp. 61-71.

National Science Foundation (2010) Science and Engineering indicators. 2010, Chapter 4. Research and Development: National Trends and International Linkages. Available at: http://www.nsf.gov/statistics/seind10/c4/c4s7.htm

Nieto, M. J. and Rodríguez, A. (2011) Offshoring of R\&D: looking abroad to improve innovation performance, Journal of International Business Studies, 42(3), pp. 345-361.

Nieto, M. J. and Rodríguez, A. (2013) The challenge of R\&D offshoring: Implications for firm productivity, in: T. Pedersen et al. (eds.): The Offshoring Challenge, Springer-Verlag.

Peteraf, M. (1993) The cornerstones of competitive advantage: A resource-based view, Strategic Management Journal, 14, pp. $179-191$. 
Ornelas, E. and Turner, J. (2008) Trade liberalization, outsourcing, and the hold-up problem, Journal of International Economics, 74(1), pp. 225-241.

Thoma, G., Torrisi, S., Gambardella, A., Guellec, D., Hall, B. H. and Harhoff, D. (2010): Harmonizing and Combining Large Datasets - An Application to Firm-Level Patent and Accounting Data, NBER Working Papers 15851, National Bureau of Economic Research, Inc.

Veugelers, R. and Cassiman, B. (2004) Foreign subsidiaries as a channel of international technology diffusion: Some direct firm level evidence from Belgium, European Economic Review, 48(2), pp. 455-476.

Williamson, O. E. (1975) Markets and Hierarchies, Free Press, N.Y.

Williamson, O. E. (1979) Transaction cost economics: The governance of contractual relations, Journal of Law and Economics, 22, pp. 233-261.

Williamson, O. E. (1981) The economics of organization: The transaction cost approach, American Journal of Sociology, 87, pp. 548-577.

Zellner, A. and D. Huang (1962) Further properties of efficient estimators for seemingly unrelated regression equations, International Economic Review, 3(3), pp. 300-313. 
Figure 1. R\&D offshoring intensity

(Percentage of R\&D imports of the total amount of R\&D purchases)

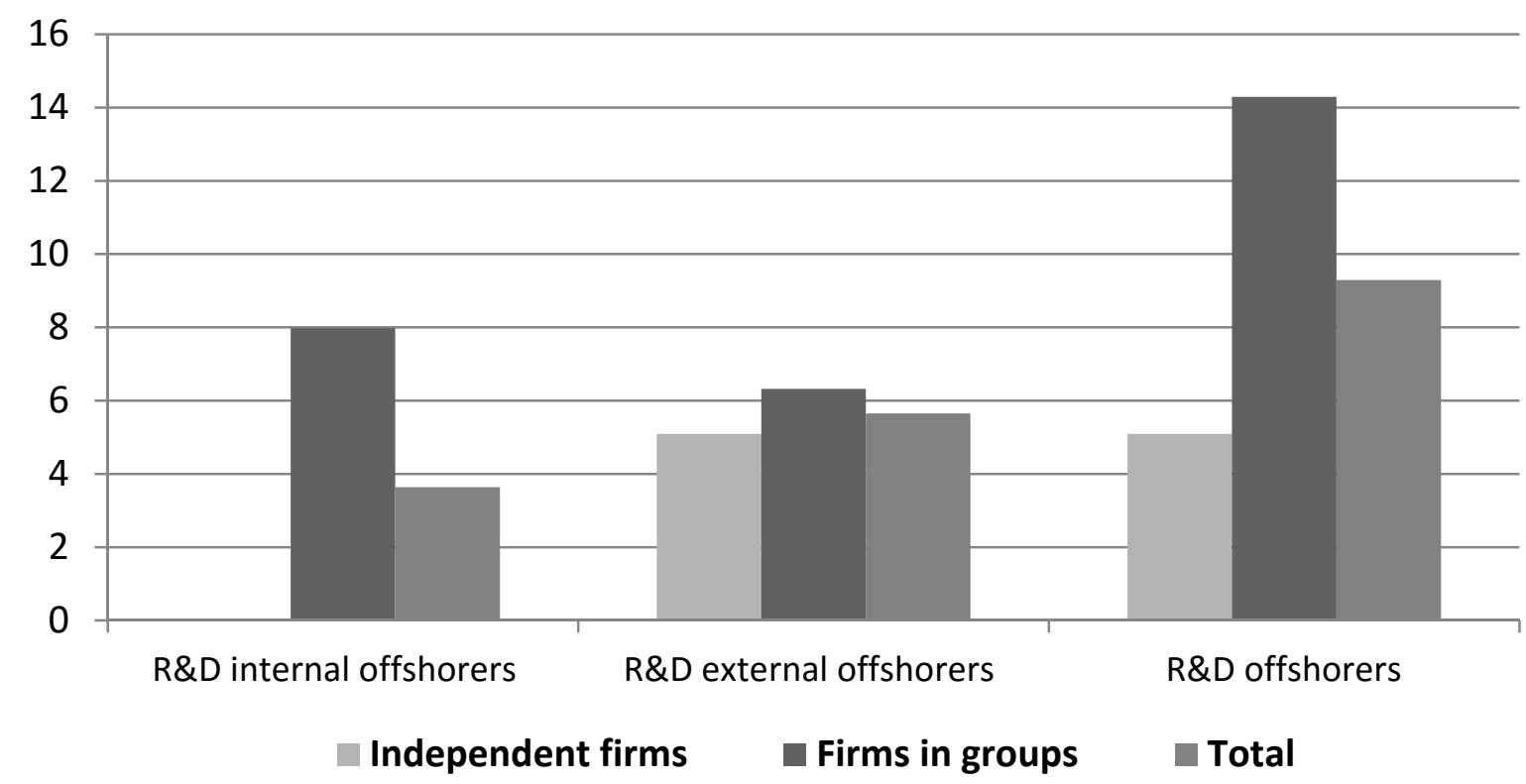

Note: Percentage calculated for offshorers with corresponding purchases. 
Table 1. R\&D offshoring in the PITEC

(Number of observations in the sample)

\begin{tabular}{lcccc}
\hline & \multicolumn{4}{c}{ R\&D offshoring } \\
\cline { 2 - 5 } & $\begin{array}{c}\text { Internal } \\
\text { offshoring }\end{array}$ & $\begin{array}{c}\text { External } \\
\text { offshoring }\end{array}$ & $\begin{array}{c}\text { Internal and external } \\
\text { offshoring }\end{array}$ & Total \\
\hline Independent firms & 0 & 1,053 & 0 & 1,053 \\
Firms in groups & $(0.0)$ & $(100.0)$ & $(0.0)$ & \\
& 955 & 1,405 & 199 & 2,160 \\
Total & $(44.2)$ & $(65.0)$ & $(9.2)$ & \multirow{2}{*}{3,214} \\
& 955 & 2.458 & 199 & \\
\hline
\end{tabular}

Note: Percentages over the total of each row are shown in parentheses. a) This column is included in the previous ones. 
Table 2. Descriptive statistics of main variables

\begin{tabular}{|c|c|c|c|c|c|}
\hline \multirow[t]{2}{*}{ Variables } & \multirow{2}{*}{ All Firms } & \multirow{2}{*}{$\begin{array}{c}\text { Firms in } \\
\text { groups }\end{array}$} & \multirow{2}{*}{$\begin{array}{l}\text { Independent } \\
\text { Firms }\end{array}$} & \multicolumn{2}{|c|}{$\begin{array}{l}\text { Difference of } \\
\text { means test }\end{array}$} \\
\hline & & & & t-test & $p$-value \\
\hline R\&D offshoring (in logarithms) & 0.76 & 1.36 & 0.37 & -32.8 & 0.000 \\
\hline$R \& D$ offshorer ${ }^{d}$ & 0.07 & 0.11 & 0.034 & -33.8 & 0.000 \\
\hline$R \& D$ offshorer from the market (external offshorer) & 0.05 & 0.74 & 0.036 & -18.8 & 0.000 \\
\hline$R \& D$ offshorer within the group (internal offshorer) ${ }^{d}$ & 0.02 & 0.50 & 0.00 & -38.9 & 0.000 \\
\hline$R \& D$ offshoring from the market (in logarithms) & 0.56 & 0.84 & 0.37 & -19.1 & 0.000 \\
\hline$R \& D$ offshoring within the group (in logarithms) & 0.25 & 0.63 & 0.00 & -31.3 & 0.000 \\
\hline \multicolumn{6}{|l|}{ Explanatory variables } \\
\hline \multicolumn{6}{|l|}{ Obstacles to innovation: } \\
\hline - Lack of financing & 1.84 & 1.67 & 1.94 & 33.4 & 0.000 \\
\hline - Lack of information & 1.24 & 1.17 & 1.28 & 14.9 & 0.000 \\
\hline \multicolumn{6}{|l|}{ Sources of information for innovation: } \\
\hline - Institutional sources ${ }^{d}$ & 0.18 & 0.17 & 0.19 & 3.2 & 0.0015 \\
\hline - Market sources ${ }^{d}$ & 0.49 & 0.49 & 0.48 & -2.0 & 0.045 \\
\hline - Internal sources ${ }^{d}$ & 0.62 & 0.67 & 0.59 & -18.5 & 0.000 \\
\hline - Relative importance of internal sources ${ }^{d}$ & 0.09 & 0.08 & 0.09 & 3.5 & 0.000 \\
\hline Exporter $^{d}$ & 0.58 & 0.66 & 0.53 & -27.3 & 0.000 \\
\hline International technological cooperation ${ }^{d}$ & 0.40 & 0.48 & 0.35 & -29.0 & 0.000 \\
\hline R\&D employment (\% of total employment) & 18.71 & 12.65 & 22.60 & 44.6 & 0.000 \\
\hline Continuous $R \& D^{d}$ & 0.78 & 0.82 & 0.74 & -17.9 & 0.000 \\
\hline Patent applicant $^{d}$ & 0.17 & 0.19 & 0.15 & -9.5 & 0.000 \\
\hline Size (in logarithms) & 4.12 & 5.04 & 3.51 & -120.0 & 0.000 \\
\hline Size squared (in logarithms) & 19.33 & 27.76 & 13.89 & -110.0 & 0.000 \\
\hline Medium and high-technology manufacturing ${ }^{d}$ & 0.33 & 0.35 & 0.32 & -6.7 & 0.000 \\
\hline Medium and high-technology services ${ }^{d}$ & 0.14 & 0.10 & 0.16 & 16.6 & 0.000 \\
\hline Foreign subsidiary $^{d}$ & 0.08 & 0.20 & 0.00 & -80.6 & 0.000 \\
\hline
\end{tabular}

Notes: $d$ = dummy variable. $t$-test denotes the difference of means test between independent firms and firms in groups. The contrast corresponds to the Wilcoxon rank-sum test (Mann-Whitney) for discrete variables. 
Table 3. Determinants of R\&D offshoring (Random effects Tobit model). All firms

\begin{tabular}{|c|c|c|c|c|c|c|}
\hline Obstacles to innovation: & \multicolumn{3}{|c|}{$\begin{array}{c}\text { (1) } \\
\text { Propensity to } \\
\text { offshore R\&D }\end{array}$} & \multicolumn{3}{|c|}{$\begin{array}{c}\text { (2) } \\
\text { Intensity of } \\
\text { R\&D offshoring }\end{array}$} \\
\hline - Lack of finance $e_{t-1}$ & -0.002 & & $(0.002)$ & -0.052 & & $(0.042)$ \\
\hline - Lack of information ${ }_{\mathrm{t}-1}$ & 0.000 & & $(0.002)$ & 0.008 & & $(0.046)$ \\
\hline \multicolumn{7}{|l|}{ Sources of information for innovation: } \\
\hline - Institutional sources $\mathrm{t}_{\mathrm{t}-1}$ & 0.007 & $* *$ & $(0.003)$ & 0.167 & $* *$ & $(0.076)$ \\
\hline - Market sources ${ }_{t-1}$ & 0.012 & $* *$ & $(0.005)$ & 0.260 & $* *$ & (0.111) \\
\hline - Internal sources $\mathrm{t}_{\mathrm{t}-1}$ & -0.005 & & $(0.005)$ & -0.119 & & (0.110) \\
\hline - Relative importance of internal sources $\mathrm{t}_{\mathrm{t}-1}$ & -0.007 & & $(0.006)$ & -0.156 & & $(0.127)$ \\
\hline Exporter $_{\mathrm{t}-1}$ & 0.021 & $* * *$ & $(0.004)$ & 0.464 & $* * *$ & $(0.085)$ \\
\hline International technological cooperation $\mathrm{t}_{\mathrm{t}-1}$ & 0.029 & $* * *$ & $(0.003)$ & 0.646 & $* * *$ & $(0.070)$ \\
\hline $\mathrm{R} \& \mathrm{D}$ employment $\mathrm{t}_{\mathrm{t}-1}$ & 0.001 & $* * *$ & $(0.000)$ & 0.015 & $* * *$ & $(0.002)$ \\
\hline Continuous R\&D & 0.025 & $* * *$ & $(0.005)$ & 0.548 & $* * *$ & $(0.104)$ \\
\hline Patent applicant $t_{t-1}$ & 0.012 & $* * *$ & $(0.003)$ & 0.265 & $* * *$ & $(0.072)$ \\
\hline Size & 0.040 & $* * *$ & $(0.007)$ & 0.892 & $* * *$ & (0.149) \\
\hline Size squared & -0.002 & $* * *$ & $(0.001)$ & -0.040 & $* * *$ & $(0.015)$ \\
\hline Medium \& high-tech manufacturing & 0.022 & $* * *$ & $(0.005)$ & 0.494 & $* * *$ & $(0.102)$ \\
\hline Medium \& high-tech services & 0.015 & $* *$ & $(0.006)$ & 0.338 & $* *$ & (0.143) \\
\hline Foreign subsidiary & 0.027 & $* * *$ & $(0.005)$ & 0.610 & $* * *$ & $(0.100)$ \\
\hline Rho & \multicolumn{6}{|c|}{$0.734(0.012)$} \\
\hline No. obs. not censured/censured & \multicolumn{6}{|c|}{$26,096 / 2,101$} \\
\hline No. observations & \multicolumn{6}{|c|}{28,197} \\
\hline
\end{tabular}

Notes: Marginal effects are reported at sample means for probability of offshoring and for the expected value of R\&D offshoring intensity conditional on offshoring R\&D. For dummy variables, the marginal effect corresponds to the discrete change from 0 to 1 . Estimated standard errors in parenthesis. (t-1) denotes that the variable is lagged one period. All regressions include the constant and time dummies. Rho is the percent contribution to the total variance of the panel-level variance component. Coefficients significant at: $1 \% * * *, 5 \% * *$, 10\%*. 
Table 4. Determinants of R\&D offshoring (Random effects Tobit model). Independent firms versus firms in groups

\begin{tabular}{|c|c|c|c|c|c|c|c|c|c|c|c|c|}
\hline \multirow[b]{3}{*}{ Obstacles to innovation: } & \multicolumn{6}{|c|}{ Independent firms } & \multicolumn{6}{|c|}{ Firms in groups } \\
\hline & \multicolumn{3}{|c|}{$\begin{array}{c}\text { (1) } \\
\text { Propensity to } \\
\text { offshore R\&D }\end{array}$} & \multicolumn{3}{|c|}{$\begin{array}{c}(2) \\
\text { Intensity of R\&D } \\
\text { offshoring }\end{array}$} & \multicolumn{3}{|c|}{$\begin{array}{l}\text { (3) } \\
\text { Propensity to } \\
\text { offshore R\&D }\end{array}$} & \multicolumn{3}{|c|}{$\begin{array}{c}(4) \\
\text { Intensity of R\&D } \\
\text { offshoring }\end{array}$} \\
\hline & & & & & & & & & & & & \\
\hline - Lack of finance $e_{t-1}$ & -0.003 & * & $(0.002)$ & -0.099 & * & $(0.060)$ & -0.001 & & $(0.004)$ & -0.017 & & $(0.062)$ \\
\hline - Lack of information ${ }_{\mathrm{t}-1}$ & 0.003 & & $(0.002)$ & 0.088 & & (0.064) & -0.005 & & (0.004) & -0.088 & & (0.071) \\
\hline \multicolumn{13}{|l|}{ Sources of information for innovation: } \\
\hline - Institutional sources $\mathrm{t}_{\mathrm{t}-1}$ & 0.008 & $* *$ & $(0.003)$ & 0.260 & $* *$ & $(0.107)$ & 0.006 & & $(0.007)$ & 0.105 & & $(0.117)$ \\
\hline - Market sources $\mathrm{t}_{\mathrm{t}-1}$ & 0.004 & & (0.005) & 0.135 & & (0.168) & 0.023 & $* *$ & (0.009) & 0.400 & $* *$ & (0.161) \\
\hline - Internal sources $\mathrm{t}_{\mathrm{t}-1}$ & 0.000 & & $(0.005)$ & 0.006 & & (0.165) & -0.012 & & $(0.009)$ & -0.211 & & $(0.160)$ \\
\hline - Relative importance of internal sources $\mathrm{t}_{\mathrm{t}-1}$ & -0.004 & & $(0.006)$ & -0.128 & & $(0.184)$ & -0.012 & & $(0.011)$ & -0.213 & & (0.189) \\
\hline Exporter $_{\mathrm{t}-1}$ & 0.016 & $* * *$ & (0.004) & 0.522 & $* * *$ & $(0.114)$ & 0.029 & $* * *$ & $(0.008)$ & 0.497 & $* * *$ & $(0.134)$ \\
\hline International technological cooperation $\mathrm{t}_{\mathrm{t}-1}$ & 0.021 & $* * *$ & $(0.004)$ & 0.679 & $* * *$ & (0.109) & 0.035 & $* * *$ & $(0.006)$ & 0.617 & $* * *$ & $(0.100)$ \\
\hline $\mathrm{R} \& \mathrm{D}$ employment $\mathrm{t}_{\mathrm{t}-1}$ & 0.0004 & $* * *$ & $(0.0001)$ & 0.011 & $* * *$ & (0.002) & 0.0014 & $* * *$ & $(0.0002)$ & 0.024 & $* * *$ & (0.003) \\
\hline Continuous R\&D & 0.016 & $* * *$ & $(0.004)$ & 0.513 & $* * *$ & (0.139) & 0.032 & $* * *$ & $(0.010)$ & 0.559 & $* * *$ & (0.169) \\
\hline Patent applicant $t_{t-1}$ & 0.008 & $* *$ & $(0.003)$ & 0.258 & $* *$ & $(0.108)$ & 0.015 & $* * *$ & $(0.006)$ & 0.269 & $* * *$ & (0.105) \\
\hline Size & 0.021 & $* * *$ & (0.008) & 0.658 & $* * *$ & $(0.242)$ & 0.082 & $* * *$ & $(0.016)$ & 1.428 & $* * *$ & (0.277) \\
\hline Size squared & -0.002 & $*$ & $(0.001)$ & -0.052 & $*$ & $(0.029)$ & -0.005 & $* * *$ & $(0.001)$ & -0.082 & $* * *$ & (0.025) \\
\hline Medium \& high-tech manufacturing & 0.009 & $* *$ & $(0.004)$ & 0.279 & $* *$ & $(0.140)$ & 0.042 & $* * *$ & $(0.009)$ & 0.724 & $* * *$ & (0.158) \\
\hline Medium \& high-tech services & 0.014 & $* * *$ & $(0.005)$ & 0.452 & $* * *$ & $(0.171)$ & 0.011 & & $(0.015)$ & 0.194 & & (0.259) \\
\hline Foreign subsidiary & & & & & & & 0.025 & $* * *$ & $(0.006)$ & 0.427 & $* * *$ & $(0.110)$ \\
\hline Rho & \multicolumn{6}{|c|}{$0.704(0.020)$} & \multicolumn{6}{|c|}{$0.768(0.014)$} \\
\hline No. obs. not censured/censured & \multicolumn{6}{|c|}{$16,362 / 707$} & \multicolumn{6}{|c|}{$9,734 / 1,394$} \\
\hline No. observations & \multicolumn{6}{|c|}{17,069} & \multicolumn{6}{|c|}{11,128} \\
\hline
\end{tabular}

Notes: Marginal effects are reported at sample means for probability of offshoring and for the expected value of R\&D offshoring intensity conditional on offshoring R\&D. For dummy variables, the marginal effect corresponds to the discrete change from 0 to 1 . Estimated standard errors in parenthesis. ( $t-1)$ denotes that the variable is lagged one period. All regressions include the constant and time dummies. Rho is the percent contribution to the total variance of the panel-level variance component. Coefficients significant at: $1 \% * * *, 5 \% * *, 10 \% *$. 


\section{Table 5. Determinants of R\&D offshoring by exporting status (Random effects Tobit model)}

\begin{tabular}{|c|c|c|c|c|c|c|c|c|}
\hline & \multicolumn{4}{|c|}{ Independent firms } & \multicolumn{4}{|c|}{ Firms in groups } \\
\hline & \multicolumn{2}{|c|}{$\begin{array}{c}\text { (1) } \\
\text { Exporting }\end{array}$} & \multicolumn{2}{|c|}{$\begin{array}{c}\text { (2) } \\
\text { Non-exporting }\end{array}$} & \multicolumn{2}{|c|}{$\begin{array}{c}(3) \\
\text { Exporting }\end{array}$} & \multicolumn{2}{|c|}{$\begin{array}{c}(4) \\
\text { Non-exporting } \\
\end{array}$} \\
\hline \multicolumn{9}{|l|}{ Obstacles to innovation: } \\
\hline - Lack of finance $e_{t-1}$ & $-0.130 *$ & $(0.075)$ & -0.120 & $(0.105)$ & -0.015 & $(0.078)$ & -0.126 & $(0.142)$ \\
\hline - Lack of information ${ }_{\mathrm{t}-1}$ & 0.125 & $(0.080)$ & 0.055 & $(0.114)$ & -0.056 & $(0.077)$ & -0.204 & $(0.150)$ \\
\hline \multicolumn{9}{|l|}{ Sources of information for innovation: } \\
\hline - Institutional sources $\mathrm{t}_{\mathrm{t}-1}$ & $0.217 *$ & $(0.139)$ & 0.240 & $(0.178)$ & 0.073 & (0.141) & -0.016 & $(0.267)$ \\
\hline - Market sources & 0.318 & $(0.206)$ & -0.218 & $(0.302)$ & $0.389 * *$ & $(0.188)$ & $0.785 * *$ & $(0.351)$ \\
\hline - Internal sources $\mathrm{t}_{\mathrm{t}-1}$ & -0.086 & $(0.200)$ & 0.297 & (0.303) & -0.225 & $(0.164)$ & -0.303 & $(0.334)$ \\
\hline - Relative importance of internal sources $\mathrm{t}_{\mathrm{t}-1}$ & -0.320 & $(0.255)$ & -0.042 & $(0.281)$ & -0.294 & & 0.531 & $(0.409)$ \\
\hline International technological cooperation $\mathrm{t}_{\mathrm{t}-1}$ & $0.584 * * *$ & $(0.130)$ & $0.925 * * *$ & (0.223) & $0.560 * * *$ & (0.139) & $1.416 * * *$ & (0.247) \\
\hline $\mathrm{R} \& \mathrm{D}$ employment $\mathrm{t}_{\mathrm{t}-1}$ & $0.019 * * *$ & $(0.003)$ & 0.004 & $(0.003)$ & $0.030 * * *$ & $(0.003)$ & $0.015 * * *$ & $(0.005)$ \\
\hline Continuous R\&D & $0.355 * *$ & (0.168) & $0.766 * * *$ & $(0.268)$ & $0.470 * *$ & (0.199) & $0.695 * *$ & $(0.343)$ \\
\hline Patent applicant $t_{t-1}$ & 0.143 & (0.132) & $0.515 * *$ & $(0.201)$ & $0.216 *$ & $(0.137)$ & $0.557 * *$ & $(0.249)$ \\
\hline Size & $0.705 * *$ & $(0.354)$ & $0.782 *$ & $(0.400)$ & $1.146 * * *$ & $(0.357)$ & $1.511 * * *$ & $(0.424)$ \\
\hline Size squared & -0.045 & $(0.042)$ & $-0.104 *$ & $(0.055)$ & -0.045 & $(0.047)$ & $-0.116 * * *$ & $(0.038)$ \\
\hline Medium \& high-tech manufacturing & $0.330 * *$ & $(0.165)$ & 0.164 & $(0.266)$ & $0.480 * * *$ & & $0.831 * * *$ & (0.308) \\
\hline Medium \& high-tech services & $0.505 * *$ & $(0.242)$ & 0.336 & $(0.242)$ & -0.137 & & 0.280 & $(0.363)$ \\
\hline Foreign subsidiary & & & & & $0.585 * * *$ & & $0.579 * *$ & $(0.295)$ \\
\hline Rho & \multicolumn{2}{|c|}{$0.719(0.023)$} & \multicolumn{2}{|c|}{$0.726(0.036)$} & \multicolumn{2}{|c|}{$0.771(0.015)$} & \multicolumn{2}{|c|}{$0.753(0.036)$} \\
\hline No. obs. not censured/censured & \multicolumn{2}{|c|}{$524 / 9,424$} & \multicolumn{2}{|c|}{$183 / 6,938$} & \multicolumn{2}{|c|}{$1,181 / 6,898$} & \multicolumn{2}{|c|}{$213 / 2,836$} \\
\hline No. observations & \multicolumn{2}{|c|}{9,948} & \multicolumn{2}{|c|}{7,121} & \multicolumn{2}{|c|}{8,079} & \multicolumn{2}{|c|}{3,049} \\
\hline
\end{tabular}

Notes: Marginal effects are reported for the expected value of R\&D offshoring intensity conditional on offshoring R\&D. For dummy variables, the marginal effect corresponds to the discrete change from 0 to 1 . Estimated standard errors in parenthesis. (t-1) denotes that the variable is lagged one period. All regressions include the constant and time dummies. Rho is the percent contribution to the total variance of the panel-level variance component. Coefficients significant at: $1 \%{ }^{* * *}, 5 \% * *, 10 \% *$. 
Table 6. Determinants of internal and external R\&D offshoring (Biprobit model). Marginal effects

Only firms in business groups

\begin{tabular}{|c|c|c|c|c|c|c|c|c|c|c|c|c|}
\hline & \multicolumn{4}{|c|}{ Univariate probabilities } & \multicolumn{8}{|c|}{ Joint probabilities } \\
\hline & $\begin{array}{r}(1) \\
\text { Inter } \\
\text { Pr(doss } \\
\end{array}$ & $\begin{array}{l}\text { nal } \\
\\
=1)\end{array}$ & $\begin{array}{r}12 \\
\text { Exte } \\
\operatorname{Pr}(\text { dos }\end{array}$ & $\begin{array}{l}\text { nal } \\
=1)\end{array}$ & $\begin{array}{r}\text { Only ir } \\
\text { Pr(doss }{ }^{\prime}=1\end{array}$ & $\begin{array}{l}\text { ternal } \\
\left.\operatorname{doss}^{E}=0\right)\end{array}$ & $\begin{array}{r}14 \\
\text { Only ex } \\
\text { Pr(doss }{ }^{\prime}=0\end{array}$ & $\begin{array}{l}\text { ternal } \\
\left.\text { doss }^{E}=1\right)\end{array}$ & $\operatorname{Pr}\left(\right.$ doss $^{\prime}=1$ & $\begin{array}{l}\text { th } \\
\text { toss } \\
\text { en }=1)\end{array}$ & $\begin{array}{r}\text { No } \\
\operatorname{Pr}\left(\text { doss }^{\prime}=\mathrm{C}\right.\end{array}$ & $\operatorname{doss}^{E}=0$ ) \\
\hline \multicolumn{13}{|l|}{ Obstacles to innovation: } \\
\hline - Lack of finance ${ }_{t-1}$ & -0.002 & $(0.002)$ & 0.004 & $(0.003)$ & -0.002 & $(0.001)$ & 0.004 & $(0.003)$ & -0.000 & $(0.000)$ & -0.002 & $(0.003)$ \\
\hline - Lack of information ${ }_{\mathrm{t}-1}$ & $-0.004^{*}$ & $(0.002)$ & $-0.007 * *$ & $(0.003)$ & -0.002 & $(0.002)$ & $-0.006^{*}$ & $(0.003)$ & $-0.001 * *$ & $(0.000)$ & $0.010 * *$ & $(0.004)$ \\
\hline \multicolumn{13}{|l|}{ Sources of information: } \\
\hline - Institutional sources $\mathrm{t}_{\mathrm{t}-1}$ & -0.001 & $(0.003)$ & $0.012 * *$ & $(0.006)$ & -0.002 & $(0.003)$ & $0.011^{* *}$ & $(0.005)$ & 0.001 & $(0.001)$ & -0.010 & $(0.006)$ \\
\hline - Market sources $\mathrm{t}_{\mathrm{t}-1}$ & -0.002 & $(0.006)$ & $0.041 * * *$ & $(0.008)$ & -0.005 & $(0.005)$ & $0.038 * * *$ & $(0.007)$ & $0.002^{*}$ & $(0.001)$ & $-0.036 * * *$ & $(0.009)$ \\
\hline - Internal sources $\mathrm{t}_{\mathrm{t}-1}$ & 0.001 & $(0.006)$ & $-0.038 * * *$ & $(0.007)$ & 0.004 & $(0.005)$ & $-0.035^{* * *}$ & $(0.007)$ & $-0.002 *$ & $(0.001)$ & $0.034 * * *$ & $(0.009)$ \\
\hline - Relative import. internal sources $\mathrm{t}_{\mathrm{t}-1}$ & 0.010 & $(0.007)$ & $-0.019 * *$ & (0.009) & $0.010 *$ & $(0.006)$ & $-0.019 * *$ & $(0.008)$ & 0.000 & $(0.001)$ & 0.009 & $(0.010)$ \\
\hline Exporter $_{\mathrm{t}-1}$ & $0.023 * * *$ & $(0.003)$ & $0.018^{* * *}$ & $(0.005)$ & $0.018 * * *$ & $(0.003)$ & $0.012 * *$ & $(0.005)$ & $0.005^{* * *}$ & $(0.001)$ & $-0.036 * * *$ & $(0.006)$ \\
\hline International tech. cooperation $\mathrm{t}_{\mathrm{t}-1}$ & $0.028 * * *$ & $(0.004)$ & $0.080 * * *$ & $(0.007)$ & $0.016 * * *$ & $(0.003)$ & $0.067 * * *$ & $(0.007)$ & $0.012 * * *$ & $(0.002)$ & $-0.096 * * *$ & $(0.008)$ \\
\hline$R \& D$ employment $t_{t-1}$ & $0.0004 * * *$ & $(0.0001)$ & $0.002 * * *$ & $(0.0001)$ & $0.0002 * *$ & $(0.0001)$ & $0.002 * * *$ & $(0.0001)$ & $0.0002 * * *$ & $(0.00003)$ & $-0.002 * * *$ & $(0.000)$ \\
\hline Continuous R\&D & 0.003 & $(0.004)$ & $0.032 * * *$ & $(0.006)$ & 0.001 & $(0.004)$ & $0.029 * * *$ & $(0.006)$ & $0.003^{* * *}$ & $(0.001)$ & $-0.033 * * *$ & $(0.007)$ \\
\hline Patent applicant $t_{t-1}$ & 0.004 & $(0.003)$ & $0.039 * * *$ & $(0.006)$ & 0.001 & $(0.003)$ & $0.036^{* * *}$ & $(0.006)$ & $0.003 * * *$ & $(0.001)$ & $-0.040 * * *$ & $(0.007)$ \\
\hline Size & $0.032 * * *$ & $(0.006)$ & $0.068 * * *$ & (0.009) & $0.021 * * *$ & $(0.005)$ & $0.057^{* * *}$ & $(0.008)$ & $0.010 * * *$ & $(0.002)$ & $-0.089 * * *$ & $(0.011)$ \\
\hline Size squared & $-0.002 * * *$ & $(0.001)$ & $-0.004 * * *$ & $(0.001)$ & $-0.001 * * *$ & $(0.0004)$ & $-0.004^{* * *}$ & $(0.001)$ & $-0.001 * * *$ & $(0.000)$ & $0.006 * * *$ & $(0.001)$ \\
\hline Medium \& high-tech manufacturing & $0.010 * * *$ & $(0.003)$ & $0.020 * * *$ & $(0.005)$ & $0.007 * * *$ & $(0.003)$ & $0.017 * * *$ & $(0.005)$ & $0.003 * * *$ & $(0.001)$ & $-0.027 * * *$ & $(0.006)$ \\
\hline Medium \& high-tech services & $0.011^{*}$ & $(0.007)$ & $-0.025 * * *$ & $(0.007)$ & $0.012^{*}$ & $(0.006)$ & $-0.025 * * *$ & $(0.007)$ & -0.000 & $(0.001)$ & 0.013 & $(0.010)$ \\
\hline Foreign subsidiary & $0.071 * * *$ & $(0.007)$ & $-0.013 * *$ & $(0.006)$ & $0.062 * * *$ & $(0.006)$ & $-0.022 * * *$ & $(0.005)$ & $0.009 * * *$ & $(0.002)$ & $-0.049 * * *$ & $(0.008)$ \\
\hline$\rho_{I E}$ & \multicolumn{4}{|c|}{$0.335^{* * *}(0.030)$} & & & & & & & & \\
\hline No. observations & \multicolumn{4}{|c|}{11,980} & & & & & & & & \\
\hline
\end{tabular}

Notes: Estimated standard errors in parenthesis. (t-1) denotes that the variable is lagged one period. All regressions include the constant and time dummies. Coefficients significant at: $1 \%^{* * *}, 5 \% * *, 10 \% *$. 
Table A1. Determinants of R\&D offshoring by technological level (Random effects Tobit model)

\begin{tabular}{|c|c|c|c|c|c|c|c|c|}
\hline & \multicolumn{4}{|c|}{ Independent firms } & \multicolumn{4}{|c|}{ Firms in groups } \\
\hline & \multicolumn{2}{|c|}{$\begin{array}{c}(1) \\
\text { High-tech }\end{array}$} & \multicolumn{2}{|c|}{$\begin{array}{c}(2) \\
\text { Low-tech }\end{array}$} & \multicolumn{2}{|c|}{$\begin{array}{c}(3) \\
\text { High-tech }\end{array}$} & \multicolumn{2}{|c|}{$\begin{array}{c}(4) \\
\text { Low-tech }\end{array}$} \\
\hline \multicolumn{9}{|l|}{ Obstacles to innovation: } \\
\hline - Lack of finance $e_{t-1}$ & -0.044 & $(0.078)$ & $-0.196 * *$ & $(0.096)$ & -0.022 & (0.078) & -0.051 & (0.099) \\
\hline - Lack of information ${ }_{\mathrm{t}-1}$ & 0.122 & $(0.082)$ & 0.083 & (0.105) & -0.115 & (0.077) & -0.024 & (0.113) \\
\hline \multicolumn{9}{|l|}{ Sources of information for innovation: } \\
\hline - Institutional sourcest-1 & $0.236 *$ & $(0.141)$ & 0.192 & (0.169) & -0.113 & $(0.141)$ & $0.429 * *$ & $(0.179)$ \\
\hline - Market sources $\mathrm{t}_{\mathrm{t}-1}$ & 0.219 & $(0.212)$ & -0.058 & (0.288) & 0.341 & (0.188) & $0.570 * *$ & $(0.250)$ \\
\hline - Internal sources $\mathrm{t}_{\mathrm{t}-1}$ & -0.088 & $(0.210)$ & 0.177 & $(0.281)$ & -0.344 & $(0.164)$ & -0.128 & $(0.250)$ \\
\hline - Relative importance of internal sources $\mathrm{t}_{\mathrm{t}-1}$ & -0.198 & $(0.235)$ & -0.098 & $(0.304)$ & $-0.505 * *$ & & 0.265 & $(0.288)$ \\
\hline Exporter $_{t-1}$ & $0.617 * * *$ & $(0.145)$ & $0.336 *$ & (0.181) & $0.343 *$ & (0.149) & $0.605 * * *$ & (0.188) \\
\hline International technological cooperation ${ }_{t-1}$ & $0.700 * * *$ & $(0.139)$ & $0.732 * * *$ & $(0.177)$ & $0.729 * * *$ & (0.139) & $0.472 * * *$ & $(0.164)$ \\
\hline $\mathrm{R} \& \mathrm{D}$ employment $\mathrm{t}_{\mathrm{t}-1}$ & $0.016 * * *$ & $(0.003)$ & 0.004 & $(0.004)$ & $0.025 * * *$ & (0.003) & $0.015 * * *$ & (0.006) \\
\hline Continuous R\&D & $0.591 * * *$ & (0.198) & $0.482 * *$ & (0.199) & $0.924 * * *$ & (0.199) & 0.349 & $(0.214)$ \\
\hline Patent applicant $t_{t-1}$ & $0.233^{*}$ & $(0.137)$ & 0.280 & $(0.182)$ & $0.266 * *$ & $(0.137)$ & 0.281 & $(0.182)$ \\
\hline Size & 0.380 & $(0.357)$ & $0.700 *$ & $(0.375)$ & $1.623 * * *$ & $(0.357)$ & $0.924 * *$ & $(0.387)$ \\
\hline Size squared & -0.003 & $(0.047)$ & $-0.071 *$ & $(0.043)$ & $-0.085 * *$ & (0.047) & -0.052 & (0.033) \\
\hline Foreign subsidiary & & & & & 0.227 & & $1.033 * * *$ & (0.192) \\
\hline Rho & \multicolumn{2}{|c|}{$0.704(0.025)$} & \multicolumn{2}{|c|}{$0.726(0.032)$} & \multicolumn{2}{|c|}{$0.768(0.018)$} & \multicolumn{2}{|c|}{$0.768(0.023)$} \\
\hline No. obs. not censured/censured & \multicolumn{2}{|c|}{$471 / 9,155$} & \multicolumn{2}{|c|}{$236 / 7,207$} & \multicolumn{2}{|c|}{$922 / 5,142$} & \multicolumn{2}{|c|}{$472 / 4,592$} \\
\hline No. observations & \multicolumn{2}{|c|}{9,626} & \multicolumn{2}{|c|}{7,443} & \multicolumn{2}{|c|}{6,064} & \multicolumn{2}{|c|}{5,064} \\
\hline
\end{tabular}

Notes: Marginal effects are reported for the expected value of R\&D offshoring intensity conditional on offshoring R\&D. For dummy variables, the marginal effect corresponds to the discrete change from 0 to 1 . Estimated standard errors in parenthesis. (t-1) denotes that the variable is lagged one period. All regressions include the constant and time dummies. Rho is the percent contribution to the total variance of the panel-level variance component. Coefficients significant at: $1 \% * * *, 5 \% * *, 10 \% *$. 